\title{
Better than nothing? Is non-union partnership a contradiction in terms?
}

\section{Stewart Johnstone, Peter Ackers and Adrian Wilkinson}

$10 / 07 / 2009$

7732 words

Stewart Johnstone, Business School, Loughborough University, Loughborough, LE11 3TU, UK. Email: s.johnstone@lboro.ac.uk

Tel: $+44(0) 1509223649$ (***Corresponding author)

Adrian Wilkinson, Department of Employment Relations, Griffith Business School, Griffith University, Nathan, QLD 4111, Australia. Tel: (00) 6173735 6792. Fax: (00) 61737357177

Email adrian.wilkinson@griffith.edu.au

Peter Ackers, Business School, Loughborough University, Loughborough, LE11 3TU, UK. Email p.ackers@lboro.ac.uk

Tel: +44 (0) 1509223100 Fax: +44 (0) 1509223961 



\title{
Better than nothing? Is non-union partnership a contradiction in terms?
}

\begin{abstract}
Though the notion of union-management partnership commands an extensive body of literature, little is known about non-union partnership arrangements. This article addresses the relatively unexplored issue of non-union partnership through a detailed case study of WebBank, a British internet bank. Three main themes are explored. Firstly, we seek to understand more about the meaning of - and rationale for partnership in non-union settings. Secondly, we explore the operation of non-union partnership in practice. Finally, we evaluate the effectiveness of non-union partnership from the perspectives of various organisational actors. The article suggests that in judging the effectiveness of a partnership arrangement, or indeed any voice regime more generally, there is a need to re-consider the benchmarks for success, and to place them in the context of contemporary employment relations. The evidence suggests that it would be deeply unhelpful and inaccurate to dismiss a non-union partnership a priori as a 'contradiction in terms'.
\end{abstract}

Keywords: partnership, non-unionism, employee voice, industrial relations 


\section{Better than nothing? Is non-union partnership a contradiction in}

\section{terms?}

\section{INTRODUCTION AND BACKGROUND}

Since the early 1990s the concept of a partnership approach to employment relations has attracted great attention in the UK from the New Labour government (DTI, 1998), the Trade Union Congress (TUC, 1999), and most of the major British trade unions. The partnership phenomenon, underpinned by the proposition that it can be both economically effective and ethically responsible for employers to co-operate with unions and employees on certain issues (Stuart and Martinez-Lucio, 2004), has also attracted significant academic attention over the last decade. Many commentaries have explored partnership as union revitalisation strategy (see for example Badigannavar and Kelly, 2005; Haynes and Allen, 2001; McBride and Stirling, 2002; Samuel, 2007; Wills 2004), while others have investigated the potential achievement of 'mutual gains' and the distribution of the 'balance of advantage' (e.g. Danford et.al, 2004; Guest and Peccei, 2001; Suff and Williams, 2004). While many of the initial empirical studies were critical in tone (Stuart and Martinez-Lucio, 2004), more recent accounts suggest a need to understand more about various preconditions, such as the underlying management and union strategies, rationale for partnership, and the way in which it has been implemented in practice (Oxenbridge and Brown, 2004; Roche and Geary, 2003; Samuel, 2007). This has led to an increasing acknowledgement of the heterogeneity of partnership arrangements, and attempts to categorise different forms of partnership across variables, including formal $v$ informal, private $v$ public sector, and union $v$ non- 
union (Johnstone et.al, 2009). Following over a decade of research, a lack of agreement on the effectiveness and sustainability of existing partnership agreements in the UK also remains, with some researchers moderately optimistic (Bacon and Samuel, 2009) while others are decidedly more uncertain (Heery, 2009).

It is the issue of non-union partnership which forms the focus of this article. Despite the rich British partnership literature, few studies have explicitly focused upon non-union instances of partnership (noteworthy exceptions include Badigannavar and Kelly, 2005 and Upchurch et.al, 2006). This probably reflects a combination of factors including the focus of much British IR research on unionised workplaces (Kaufman, 2008), and the fact that non-union instances of prima facie partnership are difficult - though not impossible - to identify. The possibility of a non-union partnership seems to be permissible under the broad definitions of partnership promulgated by New Labour, Confederation of British Industry, Chartered Institute of Personnel and Development and the Involvement and Participation Association, though understandably not the TUC. Thus, there seems to be no particular reason to rule out the possibility of non-union partnerships (Ackers et.al, 2004; Dietz et.al, 2005; Guest and Peccei, 2001), and a need for further studies of such arrangements has been identified (Stuart and MartinezLucio, 2004). ${ }^{\text {i }}$

There are important reasons to study non-union voice within the UK context. Firstly, non-union voice is an under-researched phenomenon compared with union voice, despite the fact union voice is now a minority phenomenon (Dundon et.al, 2005; Kersley 
et.al, 2006). Quantitative studies depict the demise of traditional collective industrial relations, with Millward et.al $(2000,234)$ concluding that collective IR characterised by independent trade unions "no longer represents a dominant model", and other chart the increase in 'never membership' (Bryson and Gomez, 2005). In the majority of British workplaces there is no employee access to any union or non-union indirect representation (Charlwood and Terry, 2007). However, this is strongly related to factors such as sector, as it is much more likely to be true of private sector workplaces, and representation is more likely in large workplaces (Charlwood and Terry, 2007). There is also evidence of the 'hollowing out' of unions even where they do remain present, with workplaces with union recognition but no collective bargaining coverage a manifestation of this (Brown et.al, 1998; Millward et.al, 2000; Blanchflower et.al, 2007). Where union representatives remain they "are not the negotiators, the co-authors of 'joint rules' that we have generally taken them for since the late 1960s" (Terry, 2003, 488). This pessimistic picture is reinforced by qualitative studies which question the efficacy of non-union voice structures (Gollan, 2007; Lloyd, 2001; Terry, 1999)

The findings from the relatively few studies of non-union partnership are mixed. On the one hand, Dietz et.al (2005) suggest that an enduring and generally successfully nonunion partnership is possible. IRS (2000) find that non-union partnerships appear to be even more 'deep-rooted' than union structures, while Knell (1999) concludes that there are negligible differences between the efficacy of union and non-union partnerships. On other hand, Upchurch et.al identify a "paradox of intention" with partnership becoming "the reverse mirror of its own ambitions, reflecting the very opposite of its claimed 
intent", affording limited employee voice and reinforcing managerial prerogative (Upchurch et.al, 2006, 408). In the non-union retail sector, Badigannavar and Kelly $(2005,1543)$ also conclude that in their case study organisation, partnership was in reality characterised by employee discontent and disillusionment, and "precarious as well as ineffective".

This article addresses three main issues. Firstly, it aims to develop a clearer understanding of the meaning of - and rationale for - partnership in non-union organisations. Secondly, it aims to shed light upon the operation of a contemporary non-union partnership in practice, and in particular the nature of decision making processes which are central to partnership (Haynes and Allen, 2001; Stuart and Martinez-Lucio, 2004). Thirdly, it aims to evaluate the efficacy of such arrangements from the perspectives of organisational actors. Building upon the mainstream employee involvement (EI) literature (Marchington et.al, 1992; Marchington and Wilkinson, 2005), we use scope and degree of decision making, as well as actor relationships, as dimensions against which we assess effectiveness. The rest of the paper is structured as follows. The next section outlines the research setting and methods employed in the study. This is followed by a case study of the partnership arrangements at an organisation referred to as 'WebBank'. The last part of the paper presents a discussion of these findings, before drawing some conclusions and making recommendations for further research. 


\section{RESEARCH SETTINGS AND METHOD}

Given the concern with how organisational actors understand and interpret situations in

a specific organisational context, a qualitative case study approach was deemed essential in order to capture issues of meaning and process (Bryman, 2008; Yin, 2003). The selection of cases is central to theory building from case study research (Eisenhardt, 1989). In selecting a suitable case a degree of 'purposeful sampling' was employed, in that the organisation under study is identified in IPA literature as an exemplar of 'non-union' partnership, and as such represents an unusual example of a large high-profile non-union partnership arrangement. Moreover, the structure relies upon elected full-time non-union representatives which are relatively unusual in the UK (Kersley et.al, 2006; Charlwood and Forth, 2008). Any employee with more than six months service is allowed to stand for election, and the current structure consists of three full-time and twelve part-time representatives. Part-time representatives are allocated four hours per week for their duties, and tend to deal more with day-to-day issues within the specific areas in which they work. The employer provides funds the salaries of representatives, as well as training, equipment, travel costs and stationery.

One of the main objectives of the study was to obtain the perspectives of different actors including senior managers, line managers, employee representatives, and in particular employees. The bulk of the data was gathered through semi-structured interviews conducted in 2005, which were recorded and transcribed verbatim. In addition, notes of key themes were made both during and immediately after the interviews. In total five interviews were conducted with business managers and five were conducted with a mix of full-time and part-time employee representatives. 
Managerial respondents included the HR Director, IT Manager, Operations Manager and Customer Service Manager. All interviews were conducted on a one-to-one basis, except the employee interviews where a focus group format was thought to be more $\begin{array}{lllll}\text { appropriate. } & \text { Six } & \text { focus } & \text { groups }\end{array}$ also conducted and these consisted of five employees in each group, from a crosssection of functions. Both long-serving and newer employees were targeted, in order to build a view of developments over time as well as the reactions and opinions of those new to the business. The focus groups were deliberately loosely structured and informal. All interviews lasted approximately one hour, while focus groups were of 45 minutes duration. Documentation was also examined, including the Annual report, Commitment Agreement, general company literature, conference presentations, documents and media reports. These provided useful additional material both for the purposes of triangulation, as well as to obtain a richer contextual understanding of the evolution of both the organisation and its participation processes. As with much case study research, the aim was not to generate findings which are generalisable to other organisations, but rather to generate findings which contribute to broader theory, i.e. 'analytical' or 'theoretical' generalisation (Eisenhardt, 1989; Yin, 2003). The particular sectoral, technological, product and market dynamics mean the findings are not automatically transferable to other contexts (Belanger and Edwards, 2007).

\section{FINDINGS: PARTNERSHIP AT WEBBANK}

WebBank provides internet based financial services and is a major UK e-commerce company. Established in the late 1990s, the company is owned by a major international 
financial services group. The unit of analysis was the main operations centre, located in a Midlands city better known for aerospace, engineering and manufacturing than for financial services. The site has grown from employing just 150 to over 2500 workers, and is based on a large out-of-town development which acts as the administrative head office, and also hosts the customer service, technology and operations centres. The working environment is open plan, modern and spacious and the majority of the workforce is young (the average age of a manager is 32). Roles range from entry level call centre employees through to professional and specialist positions.

\section{Evolution}

The Employee Forum was introduced in 2000 two years after the company was founded. The initiative was said to have come from the management team, in response to the rapid growth of the organisation, and the HR Director commented how "it's very difficult to consult with 2000 people individually". He suggested that the introduction of the forum preceded European legislative requirements and "fortunately the legislation is friendly to what we and the forum are doing". The creation of a representative body soon after launch may also reflect that these are 'the norm' in the UK financial service sector. Initially, the focus was said to be on low level issues: canteen food, mousemats and the poor quality of the soap in the toilets. The forum, which initially consisted of three part-time representatives was believed to be insufficient and inadequate, and the Chief Executive proposed "a need for serious re-evaluation". Representatives subsequently attended an 'employee participation workshop' with the HR team, and met representatives from the TUC Partnership Institute, trade unions, and the Involvement and Participation Association (IPA). A representative explained how "WebBank felt they 
couldn't deal with Amicus because they were too adversarial, but they took a shine to the TUC Partnership Institute feeling they were speaking the right language". The representatives also recognised that they needed some third-party support and advice, and subsequently developed a close relationship with the IPA. The three representatives devised a proposal for a new representative system consisting of elected full-time non-union employee representatives supported by a network of parttime representatives. These proposals were agreed by management in 2003 , and the

three former part-time representatives were appointed as the full-time seconded representatives in an unopposed election. The Chair of the forum has 15 years experience as a union representative in his previous employment, and several others representatives have been union members in the past. The Chair is involved in many meetings, including a monthly meeting with the Chief Executive and Director of Customer Service, while another full-time representative has monthly meetings with the Call Centre Managers and the IT Director. These meetings typically involve a review of recent issues, a business update, and reports from representatives. Representatives do not have access to the advice of union officials or training courses, although they have proactively sought opportunities to network with other non-union forums in other organisations, as well as organisations such as the IPA. WebBank has also funded training opportunities on issues including employment law, discipline and grievance, performance management and health and safety.

\section{A partnership approach to consultation}

Management stressed the need to work with representatives in a collaborative way, and "to avoid an adversarial style". As the HR Director explained, "I don't experience the 
forum as an adversarial group whether they are agreeing or disagreeing. It really is much more of a partnership". The forum chair explained that for him partnership concerns establishing a common agenda and shared goals so that "both sides know what they are aiming for and are therefore on the track together". For another full-time representative the consultation model is concerned with fairness, and specifically "being fair to the business and to the individual". The agreement is outlined in a formal 'Commitment Document'.

[Insert Table 1 here]

However, it was clear that management retained their 'right to manage' under the partnership structure. The Commitment Document states that "consultation $=$ both parties views are stated and heard before a decision is made. The perspective of each party is understood by the other not necessarily agreed between them". For the Employee Chair, the purpose is ensuring that there is a clear understanding of the rationale behind business decisions but equally "They are the managers. The benefit for us is in knowing the rationale behind those decisions". The HR Director also made it clear that the forum is not a formal negotiating body, and that management and representatives do not necessarily have to actually agree on decisions. As he explained, "There would be no point consulting them if what they said didn't influence. They don't have a vote on the decision, but they do have influence in the decision." Representatives were also clear that their role was to make sure employee views were heard by management in relation to proposals, and not necessarily about always changing decisions. 


\section{Process of partnership}

In order to enhance understanding of the process of partnership, and given that the quality of such process have been said to represent the 'litmus test' of partnership (Dietz et.al, 2005), the study explored how different issues had been handled. Two aspects were considered to be of particular interest: decision making and actor relationships. In assessing decision making we assess both the scope (in terms of the range of issues) as well as degree (defined as the amount of influence). Three areas of decision making were identified, namely pay and reward, discipline and grievance, and organisational change. Key actor relationships included those between senior managers/representatives, representatives/middle managers, and representatives/employees.

\section{Decision making}

\section{Pay and working conditions}

Representatives had been involved in some pay and reward discussions, although in the capacity of an 'adviser' rather than a 'negotiator'. One issue concerned changes to the WebBank pension scheme. Historically, employees had to actively 'opt-in' to the pension scheme, but many employees had never joined as the option was believed to be overlooked among the vast amount of HR information new employees receive. The HR Director acknowledged how "it seemed ridiculous, people giving up money". The forum representatives persuaded management to change the wording on the contracts so that new employees opt-in by default. This was agreed by the management team, 
albeit reluctantly as the HR Director still believed it was "more logical to 'opt-in' to a scheme than to 'opt-out'". Representatives also persuaded management to backdate payments to the time employees commenced employment, as opposed to the opt-in date, at a cost of $£ 1$ million. The HR Director commented how, "I'm not saying that we definitely wouldn't have done it if the reps hadn't been involved, but they were very supportive of that change, and if they hadn't it might have been harder to get through".

Another issue concerned changing the bonus payment system. Representatives realised that many part-time employees were refusing their bonus, because as working mothers in receipt of family tax credits (FTCs), they lose this income if they exceeded the earning threshold. Representatives argued that this was not in the interests of the business (as employees do not have an incentive to achieve targets), and that it is clearly not in the best interests of the employee, and proposed alternative means of bonus reward in the form of vouchers. The business subsequently implemented a system of childcare vouchers as an alternative bonus option. A representative also proposed the introduction of a holiday purchase scheme, and argued that the scheme could be framed both in terms of business rationale (less sickness and unauthorised absence) as well as the employee benefit (some employees did not want to take all their holidays). A question on the proposal was included in the monthly employee survey, and the Reward Team also investigated the idea. Following the success of a pilot scheme, the holiday purchase scheme has since been implemented across the bank. Representatives had also recently joined the Reward Committee to discuss the nature and composition of reward packages, in terms of basic salary, bonus payments and 
other fringe benefits. The representatives viewed being invited to join such discussions as evidence of their success in achieving increasing 'buy-in' from the management team.

\section{Discipline and grievance}

forum representatives are also involved in discipline and grievance situations ${ }^{\mathrm{ii}}$, often around issues such as timekeeping, absenteeism and performance. As a representative explained, "We just wanted to make sure due process has been followed. You can't go from step 1 to step 5 in one move - you just can't do that". The HR Director described the representatives as "useful independent people" who could re-assess a situation following a breakdown in trust between the line manager and an employee. One case involved performance management and compliance with Financial Service Authority (FSA) regulations. A normally outstanding employee did not receive her annual pay rise because she received two 'red calls' (i.e. those which are deemed non-compliant for reasons such as giving customers incorrect information), meaning she was not eligible for a pay rise. Prior to a recent policy change, employees had been entitled to four 'red calls'. A representative intervened, and the outcome was that the employee was given another month to demonstrate her performance, after which her pay would be reviewed again.

Team leader mostly associated the forum with discipline and grievance procedures, and there was evidence to suggest that this had actually contributed to a certain degree of negativity. As one team manager commented:

"To be honest I didn't really like the forum...[at disciplinary hearings] I felt they were judging me, seeing whether I'm right or wrong, trying to catch me out. I got really uncomfortable to the point I 
wouldn't look forward to having a conversation with a forum rep. They made me nervous" (Team manager).

He qualified this by explaining how he had managed to build a stronger relationship with the representatives, even going to them for advice commenting how "they are there for me as well". Another line manager gave an example where a normally conscientious individual was almost dismissed because of a sudden poor attendance record. After forum intervention it was discovered that the employee believed he had been the bullied by a manager. Following a detailed investigation, the situation was resolved, with the employee reporting to a new line manager, and the development of an 'attendance plan'. The team manager believed that had there been no forum intervention, the problem would never have been identified.

\section{Technology restructuring}

A recent restructuring in the technology department was highlighted as a good example of joint-working between the management team and the representatives, and their evolving role in issues of organisational change. Management and representatives agreed that there had been early forum involvement in discussing the proposals, the new job roles, and the selection procedures. Representatives suggested the initial selection procedure appeared to be slightly arbitrary and pushed for a more transparent procedure, and it was believed that the final selection process was much fairer as a result of the dialogue. Moreover, there was a belief that sometimes managers can devise "pure process models" with a "logical and legally compliant" business case but "forget the human side". Representatives suggested this was a key area where the forum could add value. A senior manager hailed the benefits of the forum involvement, describing the representatives as a providing valuable insight into potential employee 
reaction. He believed they acted as a useful feedback mechanism to the management team, as well as someone employees can talk to allay their concerns.

While the scope of issues was often upon day-to-day issues with a direct impact upon employees, there was evidence that scope was increasing with time. In terms of degree of influence, much of the emphasis was upon still upon communication and information activities, although again there was evidence of increasing consultation as the structure matured, and stronger relationships developed.

\section{Relationships}

The WebBank partnership is not based upon a formal agreement, but what management and representatives described as predominantly a 'relational 'approach. The relationships between the senior management and the representatives were said to be healthy and constructive. As a senior IT manager commented, "I value the reps and recognise they can do things I can't do". Another manager noted that because representatives are all seconded company employees, they benefited from a more balanced "dual perspective". Relationships between the forum representatives and the middle management (team leader/team manager population) were described by the Employee Chair as being "harder to crack". Representatives acknowledged that sometimes middle management may appear to be drawn in opposing directions, and view the forum as "busybodies" and a hindrance to meeting their objectives especially because of their involvement in disciplinary processes. There was also the suggestion that some middle managers were "wary of the fact you talk to the Chief Executive". 
Representatives suggested there had been some progress building relationships, but that a lot still had to be done to build the necessary level of trust. Some middle managers would 'use' the forum for advice on handling a situation with a subordinate prior to making a decision. Occasionally, managers sought advice from the forum regarding an issue with an employee, or pointed people in their direction, which they viewed as a "real accolade".

Another key relationship was between employees and representatives. The HR Director suggested that there was a need to build greater awareness of the Forum among employees. Team managers suggested that employees who had not actually approached the forum for advice would probably only have a vague notion of their purpose. A representative suggested that in the early stages the representatives had very little credibility in the eyes of employees, because they were seen to follow an agenda set by management, but that things had improved. As he explained, "We had no credibility...very much manager lapdogs or HR poodles because they only ever saw us with a manager in tow." There was also a perceived risk that they could have been perceived as actually legitimising decisions as "The managers would say we are doing X, and we have consulted with Employee Forum". Representatives suggested their visibility had also improved over time through regular 'awareness events', wearing forum rugby shirts, and attending inductions to explain their role to the 'new starts'. However, many employees still had a limited knowledge of their role, querying whether they were responsible for the "perfume sale in the atrium" or the toilet refurbishment. Employees also queried whether some decisions were the result of forum input, or simply the bank being a 'good employer': 
"You don't know how much of it is the company doing alright on their own or the Employee Forum saying I think we should change that and do it this way, it'd be better for the people. You just don't know"

"I've got no negative thoughts about the company, I think the company is good in itself, but as to what degree the forum plays in that I don't know. Whether it's just a good company that will look after you and they don't have to do a great deal. They maybe don't need to do a great deal because the company's good anyway you don't know"

(Employee Focus Groups).

\section{Evaluation}

Overall there were several positive aspects of the partnership at WebBank. Firstly, positive working relationships between management and employee representatives were an important aspect of the partnership working approach. In particular, the relationships between the full-time representatives and the Chief Executive appear to be central to the success of building the structure within a relatively short period of time. Senior management were positive about what they gained from forum representatives in terms of input into organisational issues, and the forum was seen to be adding value, providing 'intelligence' and fresh perspectives, and acting as a useful checkpoint on management decision-making. Equally, representatives have experienced increased involvement over time, and have gradually been invited to provide input on more strategic issues, and being consulted earlier in the decision-making process. Their involvement now spans a wide array of both day-to-day as well as more strategic issues. Management benefited from input into decisions and information regarding employee opinion and morale. Representatives and employees had the opportunity to have their voice heard by the top management of the organisation, and even although they were not involved in formal negotiations per se, the degree of influence was increasing. The business was able to avoid making counterproductive decisions, while workers benefited from decisions which had been discussed in detail, and were 
sometimes 'fairer' than they may otherwise have been. In short, our study underlines the process-orientated and relationship-based dynamics of non-union partnership.

However, several challenges to the effectiveness of the process were evident. Much depended on the attitudes of managers involved, and there was inconsistency across the business. There was also the challenge of achieving employee buy-in and raising the profile of the forum. Though employees remembered representatives from induction sessions, there was a lack of clarity over their exact role. Representatives believed that there was a challenge convincing employees that they are not management lackeys, but that this is difficult as grassroots employees are not aware of what goes on behind the scenes. Many line managers perceived the forum to be a hindrance rather than an ally. It was suggested that there was a need to demonstrate to middle-managers how the forum can actually add value. Much appeared to hinge upon the personalities of individual managers and representatives and their ability to build a constructive rapport. The forum has been championed since its inception by a few key management and employee figures, and a concern is the impact a major change on some of the key characters and 'champions' may have on the effectiveness and sustainability of the structure. Alternatively, some questioned the ability of the forum to deal with some major difficult issue or organisational crisis, as at the time of the study the resilience of the partnership had not yet been put to the test.

\section{DISCUSSION}


Our research suggests that, in terms of the meaning of partnership, many of the official commitments and principles of the WebBank partnership mirror those espoused by the TUC and IPA (IPA, 1997; TUC, 1999), as well as those associated with most unionised partnership agreements. These include a joint commitment to business success, recognition of the legitimate role of the parties, trust, transparency, consultation, flexibility, and the quality of working life. Of course, it is also important to go beyond official policy statements and to understand what partnership meant 'on the ground'. The dominant view of management and representatives was that partnership concerned a more collaborative approach to the management of employment relations, and in particular a problem-solving approach, openness, fairness, and a joint commitment to business success. Again, these resonate with the definitions of partnership offered in the wider partnership literature (Guest and Peccei, 2001; Haynes and Allen, 2001; Martinez-Lucio and Stuart, 2004). In contrast to a climate of poor industrial relations which encouraged many unionised partnership agreements (Kelly, 2004; Oxenbridge and Brown, 2002; Wills, 2004) the focus appeared to be upon the creation of a communication channel with employees, and the provision of employee voice (Wilkinson et.al, 2004, Wilkinson et al 2007 ,Dietz et al 2009). This was said to have become particularly important as the organisation grew rapidly in a short space of time, in line with evidence that such representative structures are more common in larger organisations, and where a large number of employees are concentrated in a single location (Charlwood and Terry, 2007). A second reason was to act as a system for discipline and grievance resolution (Hirschman, 1971). It is also noteworthy that the British financial service sector which has a long history of both external and in-house 
employee representation (Morris et.al, 2001), so the perceived 'need' for a representative structure may also be due to norms of the sector. Though management recognised a need for a system of representation, most did not believe union recognition to be appropriate, suggesting that non-union partnership represented part of a specific strategy towards trade unionism and employee voice (Millward et.al, 2000; Strauss, 2006; Wood and Fenton-O'Creevy, 2005). There was limited explicit evidence that the main objective of management was to exclude or avoid unions, by quickly creating a non-union mechanism as a substitute. This remains a possibility, but did not emerge from interviews from managers or representatives. In reality, a variety of factors are likely to have shaped management choice over their preferred model of representation (Butler, 2009). Even if it was partly a union avoidance strategy, it is still possible that the structure may be delivering benefits to employees, as management have a vested interest in making their preferred structure 'work' (Ackers et.al, 2004).

The case also explores the process of partnership. In terms of the nature of decision making processes which are central to partnership (Haynes and Allen, 2001; Dietz et.al, 2005; Stuart and Martinez-Lucio, 2004), it was clear that partnership did not concern joint decision making, but early consultation and the opportunity for representatives to comment on proposals at an early stage, and feedback employee views. In terms of degree, the focus was therefore primarily upon communication and information, but with increasing evidence of consultation, but especially where management believed this may benefit the business. Partnership concerned problems solving and some 
consultation but with management reserving the right to make the final decision, an approach British trade unions have often dismissed as 'second best' (Terry, 2003). This reflects the findings of a study into non-union partnership by Upchurch et.al $(2006,407)$ where "much information was provided by management on workplace change" but the structure was not always able to "persuade and invoke change". Nevertheless, evidence from the union management research also suggests that both the balance of power (Kelly, 2004) and advantage are often skewed in favour of management (Guest and Peccei, 2001). Clearly this is a balancing act for if the representative body does not develop any sense of independence, legitimacy or credibility it will not serve the purpose for which management intended it. Equally, if it does indeed develop a 'strong' voice it may be perceived as a threat to management.

In terms of the benefits of partnership, the case reveals that at the time of the study most organisational actors were supportive of the principles of partnership, and with the evolving non-union structure. Senior management suggested that they did not believe a trade union was an essential component of partnership, and claimed the dominant attitude to unions was ambivalence rather than avoidance. This reflects the findings of WERS 2004 that while most managers declare their position in relation to unions as ambivalence, most still prefer to communicate with workers without a third party intermediary (Kersley et.al, 2006). Representatives were also supportive of partnership but were unsure of what a union could would add, reflecting arguments that unions need to demonstrate their "value-addedness" (Terry, 1999, 28). The positive relationships forged between non-union employee representatives and senior 
management also confirms the findings of WERS 2004 (Kersley et.al, 2006). Employee focus groups revealed little support for union militancy, with the dominant view that "times have changed", and though employee attitudes to union membership were mixed, the majority of employees interviewed were unconvinced by the potential benefits over non-union representation, and supported the current non-union arrangements (Bryson, 2004; Bryson and Freeman, 2006; Guest and Conway, 2004). Representatives admitted that there was a challenge convincing employees that they are not management lackeys, as grassroots employees are not always aware of happens behind the scenes or what they have achieved. Such concerns also arise with union-management partnerships (Greene, A-M. 2000; Oxenbridge and Brown, 2004). The findings thus support those of Dietz et.al $(2005,302)$ who also identified an example of a non-union partnership "working effectively and popularly".

\section{CONCLUSIONS}

In judging the effectiveness of any partnership agreement or voice regime there is a need to re-consider the benchmarks for success, and to place them in the context of contemporary national employment relations. Charlwood and Terry (2007) note how employee representation is often judged in accordance with a romantic idealised benchmark of joint regulation between management and unions, resulting in better pay and conditions and procedural fairness. As they state, this was probably only applicable in a small minority of workplaces at the peak of trade union power. Such high benchmarks lead to a general pessimism among some industrial relations commentators regarding the efficacy of partnership. For example, Upchurch et.al (2006) 
are critical of a non-union partnership in the finance sector which they state did not deliver "equal dialogue" or even "economic and industrial democracy". Yet as Terry $(2003,460)$ states:

"The concept of joint regulation, long seen as the normative cornerstone of British industrial relations, clear evidence of unions capacity to influence the policies and practices of employers, has to be set aside"

Accordingly, there is a need to bear in mind the shift away from negotiation to consultation that has been occurring in the UK for many years (Cully et.al, 1999; Brown et.al, 2000; Kersley et.al, 2006).

There is also a tendency to compare union and non-union voice, rather than non-union voice with no voice (Haynes, 2005). It is also important to remember than weak ineffective union structures exist. We should also pay attention to what workplace actors think about non-union partnership and voice, and not to make deductions from general theories which are inextricably linked to industrial relations frames of reference (Fox, 1974), given that radicals tend to focus on outcomes, while pluralists tend to perceive intrinsic value in the very process of voice itself (Clegg, 1975). For contemporary neo-pluralists (Ackers, 2002), non-union bodies may serve a useful function as a process, channelling employee opinion into the decision making processes, independently of the outcomes they yield. Conversely, a radical may dismiss such an arrangement as inevitably superficial and ineffectual. Finally, there is a need to remember in the majority of UK workplaces there is no access to union or 
non-union representation (Charlwood and Terry, 2007; Kersley, 2006), and in these circumstances something is better than nothing (Haynes, 2005; Pfeffer, 1994).

This article has provided a much needed empirical insight into the relatively unknown arena of non-union partnership. Though the operation and effectiveness is far from perfect, it would be deeply unhelpful to dismiss non-union partnership as a 'contradiction in terms'. As Ackers et.al (2004, 41) argue, "non-union consultative employment relations are no longer a deviant, immature, or unstable form, but one of two relatively stable partnership poles". Clearly, with union membership a minority phenomenon outside the public sector (Blanchflower et.al, 2007), and evidence suggesting that employees want voice but not necessarily union voice (Diamond and Freeman, 2001) further empirical research is required which investigates the efficacy of various forms of non-union representation including partnership arrangements. Further contributions could trace the development of non-union representative processes and actor experiences over time.

\footnotetext{
${ }^{i}$ For analytical reasons it may be preferable to reserve the term 'partnership' for relations between independent trade unions and employers and to discuss non-union representative arrangements in terms of 'voice' (Marchington et.al, 2001). However, academics, policymakers and practitioners have already breached these borders. Whatever the terminology used, it remains crucial that we can compare empirically the efficacy of non-union and union forms.
} 
${ }^{\text {ii }}$ Forum involvement in discipline and grievance issues had long preceded the Employment Act 2002 and the detailed regulations made to implement the provisions of the Employment Act 2002 (Dispute Resolution) Regulations 2004 (SI 2004/752).

\section{NOTE}

This article draws on Stewart Johnstone's doctoral research, which will be published in Johnstone, S. (2009) Labour and Management Cooperation: Workplace Partnership in UK Financial Services, Basingstoke: Gower.

\section{REFERENCES}

Ackers, P. Marchington, M. Wilkinson, A. and Dundon, T. (2004) Partnership and voice: with and without trade unions: changing British approaches to participation in Partnership and Modernisation in Employment Relations, London, Routledge, pp.39-75.

Ackers, P. (2002) Reframing employment relations: the case for neo-pluralism, Industrial Relations Journal, 33(1), 2-19.

Ackers, P. and Payne, J. (1998) British trade unions and social partnership: rhetoric, reality and strategy, International Journal of Human Resource Management, 9(3), 529-549.

Bacon, N.; Samuel, P. (2009) Partnership agreement adoption and survival in the British private and public sectors, Work Employment and Society, 23(2), 231-248.

Badigannavar, V. and Kelly, J. (2005) Labour-management partnership in the non-union retail sector, International Journal of Human Resource Management, 16(8), 1529-1544.

Belanger, J. and Edwards, P. (2007) The conditions promoting compromise in the workplace. British Journal of Industrial Relations, 45(4), 713-734.

Blanchflower, D. And Bryson, A. (2007) Workplace industrial relations in Britain, 1980-2004, Industrial Relations Journal, 34(4), 285-302.

Blanchflower, D. And Bryson, A. (2008) Union decline in Britain, CEP Discussion Paper No. 884, Centre of Economic Performance, London School of Economics.

Brown, W. Deakin, S. Nash, D. And Oxenbridge, S. (2000) The employment contract: from collective procedures to individual rights, British Journal of Industrial Relations, 38(4), pp.611-629. 
Brown, W. Deakin, S. Hudson, M. and Pratten, C. (2001) The limits of statutory trade union recognition, Industrial Relations Journal, 32(3), 180-194.

Bryman, A. (2008) Social Research Methods, Oxford University Press, Oxford.

Bryson, A. (2004) Managerial responsiveness to union and non-union worker voice in Britain, Industrial Relations, 43(1), 213-241.

Bryson, A. and Gomez, R. (2005) Why have workers stopped joining unions? The rise in nevermembership in Britain, British Journal of Industrial Relations, 41(1), 67-92.

Bryson, A. and Freeman, R. (2006) What do British workers want? CEP Discussion Paper 731, July, London School of Economics and Political Science.

Bryson, A. Charlwood, A. and Forth, J. (2006) Worker voice, managerial response and labour productivity: an empirical investigation, Industrial Relations Journal, 37(5), 438-455.

Butler, P. (2009) Ride along the crest of a wave: tracking the shift of rationale for non-union consultation at FinanceCo, Human Resource Management Journal, 19(2), 176-193.

Charlwood, A. and Terry, M. (2007) $21^{\text {st }}$ century models of employee representation: structures, processes and outcomes, Industrial Relations Journal, 38(4), 320-337.

Charlwood, A. and Forth, J. (2008) Workplace Employee Representatives 1980-2004, National Institute of Economic and Social Research, Discussion Paper 317.

Clegg, H. (1975) Pluralism in industrial relations, British Journal of Industrial Relations, 13(3), 309-316.

Cully, M. O'Reilly, A. Woodland, S. and Dix, G. (1999) Britain at work as depicted by the 1998 Workplace Employee Relations Survey, Routledge, London.

Danford A., Richardson, M., Stewart, P., Tailby, S. and Upchurch, M. (2004) 'High Performance Work Systems and Workplace Partnership: a case study of aerospace workers', New Technology, Work and Employment, 19 (1), pp. 14-29

Diamond, W.J. and Freeman, R.B. (2001) What workers want from workplace organisations: a report to the TUC's promoting trade unionism task group, London, Trade Union Congress.

Dietz, G. Cullen, J. and Coad, A. (2005) Can there be non-union forms of workplace partnership? Employee Relations, 27(3), 289-306. 
Dietz G ,Wilkinson A and Redman T (2009) Involvement and participation in Wilkinson et al The Sage handbook of Human Resource Management (in press)

DTI. (1998) Fairness at work, Cmnd 3968. London: DTI.

Dundon, T. Wilkinson, A. Marchington, M. and Ackers, P. (2005) The management of voice in non-union organisations: managers perspectives, Employee Relations, 27(3), 307-319.

Dundon, T. and Rollinson, D. (2004) Employment relations in non-union firms, London, Routledge.

Dundon, T. Wilkinson, A. Marchington, M. and Wilkinson, A. (2004) The meanings and purpose of employee voice, International Journal of Human Resource Management, 15(6), 1149-1170.

Dundon, T. and Gollan, P. (2007) Reconceptualising voice in the non-union workplace, International Journal of Human Resource Management, 18(7) 1182-1198.

Eisenhardt, K.M. (1989) Building theories from case study research, Academy of Management Review, 14(4), 532-550.

Fox, A. (1974) Beyond contract: Worker, power and trust relations, London: Faber and Faber. Gollan, P. (2007) Employee representation in non-union firms, Sage, London.

Green, A-M. Black, J. and Ackers, P. (2000) The union makes us strong? A study of the dynamics of workplace union leadership at two UK manufacturing plants, British Journal of Industrial Relations, 38(1), 75-93.

Guest D. and Peccei R. (2001) 'Partnership at work: mutuality and the balance of advantage', British Journal of Industrial Relations, 39 (2) pp207-236.

Guest, D. And Conway, N. (2004) Exploring the paradox of unionised worker dissatisfaction, Industrial Relations Journal, 35(2), 102-121.

Haynes P. and Allen M. 'Partnership as a union strategy: a preliminary evaluation, Employee Relations, Vol. 23, No. 2, 2001. pp. 164-87.

Haynes, P. (2005) Filling the vacuum? Non-union employee voice in the Auckland hotel industry, Employee Relations, 27(3), 259-271.

Hirschman, A. (1970) Exit voice and loyalty, Cambridge, MA. Harvard University Press. 
Heery, E. (2009) The representation gap and the future of worker representation, Industrial Relations Journal, 40(4) 324-336.

IPA. (1997) Towards industrial partnership. London: IPA.

IRS (2000) Partnership at work, IRS Management Review, 17.

Johnstone, S. Ackers, P. and Wilkinson, A. (2009) The British partnership phenomenon: a ten year review. Human Resource Management Journal, 19 (3), pp. 260-279.

Johnstone, S. (2009). Labour and Management Co-operation: Workplace Partnership in UK Financial Services, Basingstoke: Gower.

Kaufman, B. (2008) Paradigms in Industrial Relations: Original, Modern and Versions In Between, British Journal of Industrial Relations, 46(2), pp.314-339.

Kelly, J. (1996) 'Union militancy and social partnership' in P. Ackers, C. Smith and C. Smith (eds). The new workplace and trade unionism. London: Routledge,

Kelly J. (2004) 'Social partnership arrangements in Britain', Industrial Relations, 43(1), pp 267-292.

Kersley, B. Alpin, C. Forth, J. Bryson, A. Bewley, H. and Oxenbridge, S. (2006) Insight the Workplace, London, Routledge.

Knell, J. (1999) Partnership at work? Employment Relations Research Series. London: DTI.

Marchington, M. Wilkinson, A. Ackers, P. and Dundon, T. (2001) Management choice and employee voice, London, CIPD.

Lloyd, C. (2001) What do employee councils so? The impact of non-union forms of representation on trade union organisation, Industrial Relations Journal, 32(4), 313-27.

Marchington, M. and Wilkinson, A. (2005) Direct participation and involvement, in S Bach (Ed) Managing human resources: personnel management in transition. Oxford, Blackwell.

McBride, J. and Stirling, J. (2002) 'Partnership and process in the maritime construction industry', Employee Relations, 24 (3), 290.

Millward, N. Bryson, A. and Forth, J. (2000) All change at work? London: Routledge.

Morris, T. Storey, J. Wilkinson, A. and Cressey, P. (2001) Industrial change and union mergers in British retail finance, British Journal of Industrial Relations, 39(2), 237-256 
Oxenbridge, S. And Brown, W. (2002) The two faces of partnership? An assessment of partnership and co-operative employer/trade unions relationships, Employee Relations, 24(3), pp.262-276.

Oxenbridge S. and Brown W. (2004) 'Developing partnership relationships: a case of leveraging power', in M. Stuart and M. Martinez-Lucio (eds), Partnership and Modernisation in Employment Relations. London, Routledge.

Pfeffer, J. (1995) Competitive advantage through people, Boston, MA, Harvard Business School Press.

Roche, W. K. and Geary, J. F. (2002) 'Advocates, critics and union involvement in workplace participation', British Journal of Industrial Relations, 40 (4), 659.

Samuel, P.J. (2007) Partnership consultation and employer domination in two British life and pension firms, Work Employment and Society, 21(3), p.459.

Stuart, M. and Martinez-Lucio, M. (2004) Partnership and Modernisation in Employment Relations. London: Routledge.

Strauss, G. (2006) Worker participation - some under-considered issues, Industrial Relations, 45(4) 779803.

Suff, R. and Williams, S. (2004) 'The myth of mutuality? Employee perceptions of partnership at Borg Warner', Employee Relations, 26 (1), 30-43.

Taras, D. And Kaufman, B. (2006 ) Non-union employee representation in North America: diversity, controversy and uncertain future, Industrial Relations Journal, 37(5), 513-542.

Tailby, S. Richardson, M. Upchurch, M. Danford, A. and Stewart, P. (2007) Partnership with and without trade unions in the UK financial services: filling or fuelling the representation gap, Industrial Relations Journal, 38(3), 210-228.

Terry, M. (1999) Systems of employee representation in non-union firms in the UK, Industrial Relations Journal 30(1), 16-30.

Terry, M. (2003) Can 'partnership' reverse the decline in British trade unions? Work, Employment and Society, 17(3), 459-472.

TUC. (1999) Partners for progress: next steps for the new unionism. London: TUC. 
Upchurch, M. Richardson, R. Tailby, S. Danford, A. and Stewart, P. (2006) Employee representation and partnership in the non-union sector: a paradox of intention, Human Resource Management Journal, 16(4), 393-410.

Wilkinson,A,Dundon,T ,Ackers P and Marchington M (2004) Changing Patterns of Employee Voice, Journal of Industrial Relations, Vol. 46, No. 3, 2004, pp. 298-322

Wilkinson A,T. Dundon and I. Grugulis(2007 )Information but not Consultation: Exploring Employee Involvement in SMEs,._International Journal of Human Resource Management, Vol 18, No 7, 2007, pp. 1279-1297.

Wills, J. (2004) 'Trade unionism and partnership in practice: evidence from the Barclays-Unifi agreement', Industrial Relations Journal, 35 (4), 329-343.

Wood, S. and Fenton-O' Creevy, M. (2005) Direct involvement, representation and employee involvement in UK multinationals in Europe, European Journal of Industrial Relations, 11(1), 27-50.

Yin, R. (2003) Case study research, Sage, London.

Table 1

The WebBank Employee Forum Commitment Document

\begin{tabular}{|c|c|}
\hline Objectives & $\begin{array}{l}\text { - To increase the level of employee involvement in change and business } \\
\text { initiatives which affect employees using effective consultation } \\
\text { - To build and maintain effective relationships with all departments } \\
\text { through consultation } \\
\text { - To represent independently and without prejudice the interests of } \\
\text { WebBank people both collectively and individually }\end{array}$ \\
\hline Primary principles & $\begin{array}{l}\text { - Joint commitment of the Employee Forum and WebBank will ensure } \\
\text { WebBank's success } \\
\text { - Recognition by all for legitimate roles, interests and responsibilities of } \\
\text { those on the Employee Forum } \\
\text { - } \quad \text { Transparency between the Employee Forum and WebBank through } \\
\text { effective consultation - sharing information policy consultation } \\
\text { - Building trust between WebBank people } \\
\text { - WebBank people have the right to be represented and have equal } \\
\text { opportunities within the business } \\
\text { - WebBank people have exceptional training and effective development }\end{array}$ \\
\hline
\end{tabular}




\begin{tabular}{l|ll}
\hline & - Source from the Employee Forum purpose \\
Operating principles & - $\begin{array}{l}\text { Act for the good of WebBank people and WebBank } \\
\text { - Stay within the overall context of WebBank's strategy, support that } \\
\end{array}$ \\
- & strategy and contribute to WebBank's game \\
\hline
\end{tabular}

